\title{
Modelling of energy transfer induced by longitudinal shaking of one atom row in carbon nanoribbons
}

\author{
I.P. Lobzenko ${ }^{1,2, \dagger}$, I. Evazzade ${ }^{3}$, M.R. Roknabadi³, R.I. Makhmutova ${ }^{4}$, S.V. Dmitriev ${ }^{2,5}$ \\ †ivan.lobzenko@gmail.com
}

\author{
${ }^{1}$ Institute of Molecule and Crystal Physics URC RAS, Prt. Oktyabrya 151, 450075, Ufa, Russia \\ ${ }^{2}$ Institute for Metals Superplasticity Problems, RAS, Khalturina 39, 450001, Ufa, Russia \\ ${ }^{3}$ Department of Physics, Ferdowsi University of Mashhad, Vakilabad Highway, 9177948974, Mashhad, Iran \\ ${ }^{4}$ Bashkir State Agrarian University, 50 let Oktyabrya 34, 450001, Ufa, Russia \\ ${ }^{5}$ Peter the Great St. Petersburg Polytechnic University, 29 Polytechnicheskaya St., 195251, St. Petersburg, Russia
}

The energy transfer affected by the presence of discrete breathers (DB) in the carbon nanoribbons is investigated by means of molecular dynamics. The nanoribbons we consider are long in the "armchair" direction and narrow in "zigzag" direction graphene planes. The system is treated under the strain with deformation components being $\varepsilon_{x x}=0.35$ (which coincides with zigzag direction), $\varepsilon_{y y}=-0.1$ (which coincides with armchair direction). Such strain applied to graphene leads to the existence of the gap in phonon spectrum and therefore to the possibility of exciting discrete breathers with frequencies within the gap. The energy transfer to the system is induced by shaking of the central zigzag chain (the carbon chain of atoms prolate in $x$ direction). The shaking is implemented by displacing each atom of the chain according to the sinusoidal function of time. It is shown that for the frequencies of shaking lying in the gap of graphene phonon spectrum there is non negligible energy transfer to the ribbon. We attribute this phenomenon with the excitation of two discrete breathers (one at each side of the shaking chain). For the frequencies of shaking being lower than the discrete breather resonant frequency the DB prevents energy transfer to the system, while for higher frequencies of shaking the DB promotes the energy spreading.

Keywords: energy transfer, discrete breathers, graphene, phonon spectrum.

\section{Моделирование переноса энергии индуцированного продоль- ными колебаниями атомного ряда в углеродных нанолентах}

\author{
Лобзенко И.П. ${ }^{1,2,}$, Еваззаде И. ${ }^{3}$, Рокнабади М.Р. ${ }^{3}$, Махмутова Р.И. ${ }^{4}$, Дмитриев С.В. ${ }^{2,5}$ \\ ${ }^{1}$ Институт физики молекул и кристаллов УНЦ РАН, пр. Октября 151, 450075, Уфа, Россия \\ ${ }^{2}$ Институт проблем сверхпластичности металлов РАН, ул Ст. Халтурина 39, 450001, Уфа, Россия \\ ${ }^{3}$ Университет им. Фирдоуси, шоссе Вакилабад, 9177948974, Машхад, Иран \\ ${ }^{4}$ Башкирский государственный аграрный университет, ул. 50 лет Октября 34, 450001, г. Уфа, Россия \\ ${ }^{5}$ Санкт-Петербургский политехнический университет Петра Великого, ул. Политехническая 29, 195251, СПб, Россия
}

\begin{abstract}
Методами молекулярной динамики исследован перенос энергии в углеродных нанолентах в присутствии дискретных бризеров. Рассмотрены наноленты протяжённые вдоль направления "кресло" и узкие вдоль направления "зигзаг" графена. Система рассматривалась под действием растяжения с компонентами $\varepsilon_{x x}=0.35$ (что соответствует растяжению в направлении "зигзаг") и $\varepsilon_{y y}=-0.1$ (что соответствует сжатию в направлении "кресло"). Указанное растяжение индуцирует появление запрещённой зоны в фононном спектре графена и таким образом ведёт к возможности возбуждения дискретных бризеров с частотами в щели спектра. Передача энергии системе осуществлялась при помощи искусственного раскачивания центрального ряда атомов, формирующих цепочку в виде зигзага (цепочка вытянута вдоль направления $x$ ). Раскачивание соответствует синусоидальными осцилляциям атомов вблизи их положений равновесия вдоль оси $y$. Показано, что для частот раскачивания, лежащих в цели фононного спектра системы, существует область ненулевой мощности передачи энергии наноленте. Показана связь этого феномена с возбуждением в системе двух дискретных бризеров (по одному с каждой стороны раскачиваемого ряда атомов). В случае частот раскачивания меньших чем резонансная частота возникающего бризера, энергия в систему передаются крайне слабо, то есть бризер препятствует распространению энергии от раскачиваемого ряда атомов в наноленту. При превышении резонаносной частоты (частоты бризера) дискретный бризер напротив способствует передаче энергии от раскачиваемого ряда наноленте.
\end{abstract}

Ключевые слова: Перенос энергии, дискретные бризеры, графен, фононный спектр. 


\section{Introduction}

The concept of discrete breathers (DB) have become very useful for describing localized excitations in defect free nonlinear lattices. Starting from the work of Sivers and Takeno [1] nonlinear dynamical objects of that type drew significant attention of the scientific community. Discrete breathers (also referred to as intrinsic localized modes or ILM) were directly observed in many macroscopic and mesoscopic system of different physical nature [2-6]. On the other hand, the theoretical investigations of discrete breathers have been also developed to demonstrate that in general every discrete nonlinear system with translational symmetry can maintain breathers $[2,7,8]$. The frequency of DB lies outside of the system phonon spectrum, which means that once excited it will not emit energy in the form of plane waves. Nevertheless the very fine tuning of the form of initial excitation is needed to introduce a perfect breather (which will not radiate energy) to the system $[9,10]$. In the physical experiments it is only possible to have breather-like localized object which can be referred to as quasi-breather $[10,11]$ and has a finite lifetime because of the energy loses during the oscillations.

The fact that discrete breathers have very weak interactions with phonon modes makes them very promising objects to be used in crystals [12]. Despite of there are several works on experimental study of DBs in crystals [13-17], their direct observation in such systems is complicated by the presence of thermally activated delocalized oscillations [18]. That enlightens computer modelling of breathers in crystals as one of the most preferable approach of their study. By means of molecular dynamic (MD) the properties of discrete breathers have already been established in several crystal lattices [19-25] Such calculations are often held in the classical framework based on the phenomenological interaction potentials. The choice of particular potential is a very sophisticated problem especially for the modelling of highly nonlinear dynamical objects such as DB. To give an example of differences in the breathers properties due to the use of different phenomenological potentials we refer to the work [26] where authors investigate the intrinsic localized modes in Si crystal. On the other hand in the work [8] it was shown that properties of discrete breathers in graphane (fully hydroginated graphene) obtained from the ab initio calculation coincide with those obtained in the classical MD [27] only in the small range of low DB amplitudes. The latter results were received with the use of the well known AIREBO potential [28].

In graphene the existence, stability and properties of discrete breathers have been studied both by means of classical MD [29-31] and ab initio calculations [32]. The latter approach overcomes the problem of phenomenological potential choice and can be used to verify the results of the former approach. It is shown in [32] that the use of the standard set of potentials for carbon and hydrocarbon systems [33] leads to the properties of DBs which are in a good agreement with those obtained from first principal calculations. That fact gives an opportunity of studying highly nonlinear excitations in graphene by means of classical molecular dynamics on relatively long time intervals that could not be achieved in ab initio calculations. Moreover, thermoconductivity of graphene nanoribbons is still not investigated well but already is considered as very high, which means that a thorough study of the energy flow in graphene is needed.

The present paper is devoted to the investigation of energy transfer mechanism in graphene nanoribbons by means of classical molecular dynamics simulations. The calculations are held using the standard set of interatomic interaction potentials in carbon and hydrocarbon structures [33] (also sometimes referred to as Savin potential). A distinctive feature of the potentials is that they reproduce the dispersion curve of graphene better than the Brenner potentials [34].

\section{The model}

A graphene sheet forms a two-dimensional hexagonal crystal lattice with a primitive cell containing two atoms. To simulate the nanoribbons, a rectangular supercell with dimensions $M \times N$ was built, where $M$ and $N$ are number of unit cells along $x$ ("zigzag" graphene direction) and $y$ ("armchair" graphene direction) axes, respectively. The periodic boundary conditions were applied to the calculation block (see Fig. 1a). The standard set of interatomic potentials gives the valent bond length in the unstrained graphene $\rho_{0}=1.418 \AA$. Without any strain applied the phonon spectrum of graphene doesn't contain a gap. As long as previous studies $[29,32]$ showed that discrete breathers in graphene are dynamical objects with soft type nonlinearity (their frequency is decreasing with increase of amplitude), we introduce a strain with the components $\varepsilon_{x x}=0.35$, $\varepsilon_{y y}=-0.1$, and $\varepsilon_{x y}=0.0$. The equilibrium positions of atoms in uniformly strained graphene are found by minimizing the potential energy of the crystal. For the chosen strain components the equilibrium flat configuration of graphene is stable [35]. The phonon density of states of our system
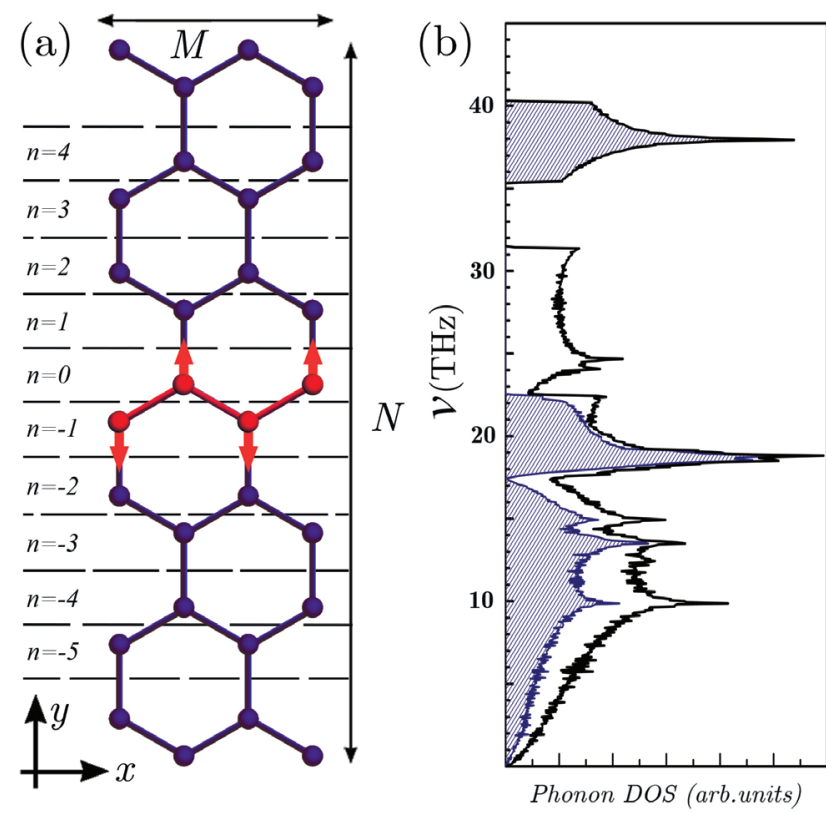

Fig. 1. (Color online) (a) Crystal lattice of graphene. The driven chain is colored in red with arrows showing the shaking pattern. (b) Phonon density of state for the system under the strain with the components $\varepsilon_{x x}=0.35, \varepsilon_{y y}=-0.1$, and $\varepsilon_{x y}=0.0$. 
under the strain is depicted in Fig. 1b. It shows a wide gap in $x y$ phonon states which makes it possible for DBs to exist with frequencies inside the gap (see [29] for the thorough discussion).

To start an energy transfer to the system we introduce a shaking of the chain of the carbon atoms in the middle of the ribbon. Since our system is longer on the $y$ direction then in $x$ direction, the atoms which are being shaking form a zigzag shaped chain. The number of atoms in that chain equals $2 M$. We choose now the most simple type of the shaking, namely the "displacement driving" one. For that case the exact displacements of the shaking atoms are in the form $\Delta y=A \sin (2 \pi v t)$, where $\Delta y$ represents the displacement of atoms from their equilibrium positions in $y$ direction, $A$ is the amplitude in angstroms and $v$ is the frequency in THz. The main quantity which describes the energy transfer is power $P=\Delta E / \Delta t$, where $\Delta E$ stands for the additional energy which came to the system through the time $\Delta t$.

\section{Results}

For the displacement driven shaking we study different frequencies $v$ and amplitudes $A$ of the driving. For each pair of parameters the time of calculation was estimated to let the excitation go just to the last particle on the each end of the graphene ribbon. Further calculations would be affected by the border effects. In the Fig. 2 the dependence of power $P$ on driving frequency $v$ is shown for the amplitude $A=0.01 \AA$. The line in blue color indicates the result for $N=200$ unit cells in $y$ direction, while the line in red - the result for $N=400$. It can be seen that $N=400$ is enough to avoid the ribbon length influence on the results. The gray doted line on Fig. 2 corresponds to the modelling of displacement driven energy transfer for the number of elementary cells in $x$ direction $M=4$. The good agreement of that result with the case of $M=1$ (red curve on Fig. 2) shows the validity of choosing $M=1$, i.e. for narrow carbon nanoribbons the width of the ribbon does not affect the energy transfer in the longitudinal direction. The question of the width influence on the energy transfer should be treated more carefully and will be published elsewhere. For all parameters set here and after (if it is not specified) the number of unit cells in $x$ direction is $M=1$.

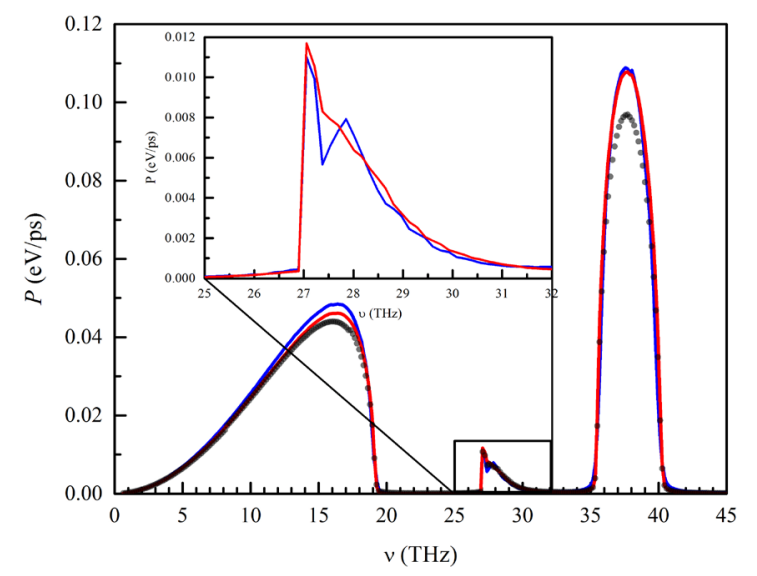

Fig. 2. (Color online) The dependence of power $P$ on driving frequency $v$ with $A=0.01 \AA$ for $N=200$ (in blue) and $N=400$ (in red). Gray doted line shows the case of number of unit sells in $x$ direction $M=4$.
The dependence of power on frequency (Fig. 2) should be compared with the phonon density of states (Fig. 1b). It is obvious that the main regions, where the energy transfer to the system is possible, coincide with the regions of $x y$ phonon waves existence (frequencies from 0 to $22.5 \mathrm{THz}$ and from 35.4 to $40.3 \mathrm{THz}$ ). Nevertheless there is the region where frequency of shaking doesn't match with any phonon wave frequency (in the gap of phonon spectrum), but still energy transfer is possible with not negligible power values. The inside picture on Fig. 2 shows the magnification of the frequency region for which shaking frequency lies in the band gap of graphene phonon spectrum. For that case energy goes to the lattice in a very special manner. On the Fig. 3 the evolution in time of two particles closest to the shaking chain is shown for two different frequencies. The Fig. 3a corresponds to the driving frequency $v=26.7 \mathrm{THz}$. It can be seen that the maximum amplitude of the atom closest to the shaking chain is 10 times higher than the driving amplitude. Nevertheless, the breather continuously loses and gains energy through the interaction with the shaking row. The result on the Fig. 3a does not coincide with the sharp peak of power transfer, located at $v_{c}=26.9 \mathrm{THz}$ (see inside picture on Fig. 2). The energy transfer for $v=26.7 \mathrm{THz}$ is very small.

The analysis of the oscillation frequencies of atoms close to the shaking chain shows that for the particular amplitude $A$ of the shaking the critical frequency $v_{c}$ corresponds to the frequency of discrete breather which appears in the system. For the case of shaking parameters $A=0.01 \AA$ and $v=26.7 \mathrm{THz}$ the frequency of DB floats close to the mean value of $v_{d b}=27.3 \mathrm{THz}$ with standard deviation $\sigma_{v d b}=0.1 \mathrm{THz}$ (see oscillations on Fig. 3a). For the case of shaking parameters $A=0.01 \AA$ and $v=27.7 \mathrm{THz}$ (above the $v_{c}=27.2 \mathrm{THz}$ for that amplitude) the frequency of $\mathrm{DB}$ floats close to the mean value of $v_{d b}=26.7 \mathrm{THz}$ with standard deviation $\sigma_{v d b}=0.6 \mathrm{THz}$ (see oscillations on Fig. 3b). As it can be seen, if the frequency of shaking lays below the frequency of $\mathrm{DB}$ which appears in the system, the energy transfer to the nanoribbon is very low, so the breather prevents the energy flow. In the case of driving frequency above the $v_{d b}$, breather promotes the energy spreading.

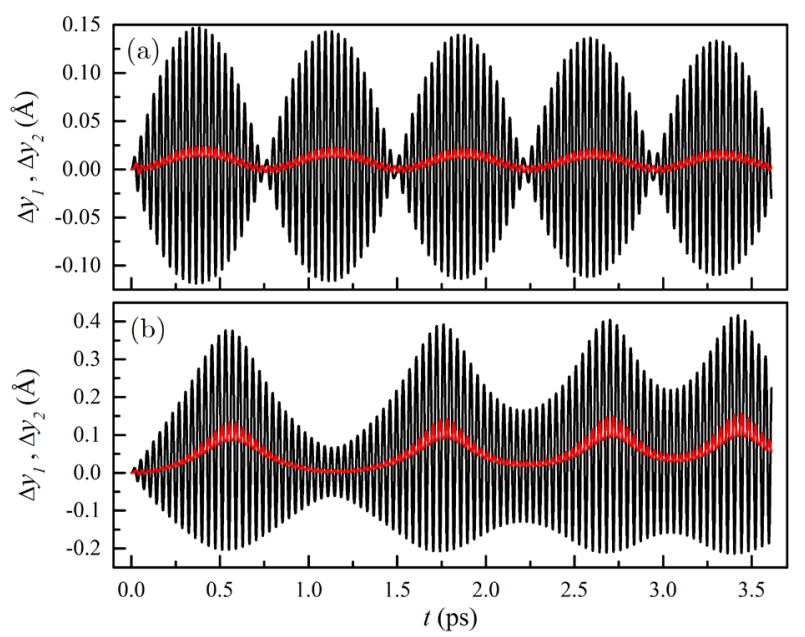

Fig. 3. (Color online) Oscillations in $y$ direction of atoms next to the shaking row. Displacement driving amplitude is $A=0.01 \AA$. Black curve shows displacements of atoms with $n=1$ while thin red curve stands for the atoms with $\mathrm{n}=2$ (see Fig. 1a); (a) shaking frequency is $v=26.7 \mathrm{THz}(\mathrm{b})$ shaking frequency is $v=27.7 \mathrm{THz}$. 


\section{Conclusion}

The simple case of displacement driven energy transfer to the carbon nanoribbon is investigated. It is shown that energy can spread over the system for shaking frequencies not only within phonon spectrum of graphene. Inside the gap of phonon spectrum there is a resonant frequency $v_{c}$ for which the power of energy transfer reaches highest values. The frequency $v_{c}$ coincides with the frequency of the DB emerging close to the shaking chain. For the given amplitude of shaking if the driving frequency is less then the DB frequency, than energy transfer to the system is very low. In the case of shaking frequencies higher than $v_{c}$ the discrete breather promotes energy flow to the ribbon due to the low frequency modulations of its' amplitude.

Acknowledgements. I.P. Lobzenko is grateful to the Program of the President for Young Scientists of Russian Federation, project no. MK-5283.2015.2. S.V. Dmitriev is grateful to the Russian Scientific Foundation for financial support, project no. 14-13-00982.

\section{References}

1. A. J. Sievers and S. Takeno, Phys. Rev. Lett. 61, 970 (1988).

2. S. Flach and A. V. Gorbach, Physics Reports 467, 1 (2008).

3. D. K. Campbell, S. Flach, and Y. S. Kivshar, Physics Today 57, 43 (2004).

4. P. Binder, D. Abraimov, A. V. Ustinov, S. Flach, and Y. Zolotaryuk, Phys. Rev. Lett. 84, 745 (2000).

5. R. Morandotti, U. Peschel, J. S. Aitchison, H. S. Eisenberg, and Y. Silberberg, Phys. Rev. Lett. 83, 2726 (1999).

6. M. Sato, B. E. Hubbard, and A. J. Sievers, Rev. Mod. Phys. 78, 137 (2006).

7. J. B. Page, Phys. Rev. B 41, 7835 (1990).

8. G. M. Chechin, S. V. Dmitriev, I. P. Lobzenko, and D. S. Ryabov, Phys. Rev. B 90, 045432 (2014).

9. J. Marin and S. Aubry, Nonlinearity 9, 1501 (1996).

10. G. M. Chechin, G.S. Dzhelauhova, and E. A. Mehonoshina, Phys. Rev. E 74, 036608 (2006).

11. G. M. Chechin and G. S. Dzhelauhova, Journal of Sound Vibration 322, 490 (2009).

12. S. V. Dmitriev, E. A. Korznikova, J. A. Baimova, and M. G. Velarde, Uspekhi Fizicheskikh Nauk 186, 471 (2016).

13. B. I. Swanson, J. A. Brozik, S. P. Love, G. F. Strouse, A. P. Shreve, A. R. Bishop, W.-Z. Wang, and M. I. Salkola, Phys. Rev. Lett. 82, 3288 (1999).
14. G. Kalosakas, A. R. Bishop, and A. P. Shreve, Phys. Rev. B 66, 094303 (2002).

15. M. Manley, M. Yethiraj, H. Sinn, H. Volz, A. Alatas, J. Lashley, W. Hults, G. Lander, and J. Smith, Physical review letters 96, 125501 (2006).

16. M. E. Manley, J. W. Lynn, Y. Chen, and G. H. Lander, Physical Review B 77, 052301 (2008).

17. M. Manley, A. Sievers, J. Lynn, S. Kiselev, N. Agladze, Y. Chen, A. Llobet, and A. Alatas, Physical Review B 79, 134304 (2009).

18. A. J. Sievers, M. Sato, J. B. Page, and T. Rössler, Phys. Rev. B 88, 104305 (2013).

19. S. A. Kiselev and A. J. Sievers, Phys. Rev. B 55, 5755 (1997).

20. L. Z. Khadeeva and S. V. Dmitriev, Phys. Rev. B 81, 214306 (2010)

21. M. Haas, V. Hizhnyakov, A. Shelkan, M. Klopov, and A. J. Sievers, Phys. Rev. B 84, 144303 (2011).

22. A. A. Kistanov, Y. A. Baimova, and S. V. Dmitriev, Tech. Phys. Lett. 38, 676 (2012).

23. A. A. Kistanov and S. V. Dmitriev, Tech. Phys. Lett. 39, 618 (2013)

24. A. A. Kistanov, S. V. Dmitriev, A. S. Semenov, V. I. Dubinko, and D. A. Terent'ev, Tech. Phys. Lett. 40, 657 (2014).

25. A. A. Kistanov, R. T. Murzaev, S. V. Dmitriev, V. I. Dubinko, and V. V. Khizhnyakov, JETP Letters 99, 353 (2014).

26. N. K. Voulgarakis, G. Hadjisavvas, P. C. Kelires, and G. P. Tsironis, Phys. Rev. B 69, 113201 (2004).

27. J. A. Baimova and S. V. Dmitriev, Russian Physics Journal 58, 785 (2015).

28. S. J. Stuart, A. B. Tutein, and J. A. Harrison, The Journal of Chemical Physics 112, 6472 (2000).

29. L. Z. Khadeeva, S. V. Dmitriev, and Y. S. Kivshar', JETP Lett., 94(7),539 (2011).

30. Y. Yamayose, Y. Kinoshita, Y. Doi, A. Nakatani, and T. Kitamura, EPL (Europhysics Letters) 80, 40008 (2007).

31. Y. Doi and A. Nakatani, Journal of Solid Mechanics and Materials Engineering 6, 71 (2012).

32. I. P. Lobzenko, G. M. Chechin, G. S. Bezuglova, Y. A. Baimova, E. A. Korznikova, and S. V. Dmitriev, Physics of the Solid State 58, 633 (2016).

33. Y. S. K. A. V. Savin and B. Hu, Phys. Rev. B 82, 195422.

34. D. W. Brenner, Phys. Rev. B 42, 9458 (1990).

35. Y. A. Baimova, S. V. Dmitriev, A. V. Savin, and Y. S. Kivshar', Physics of the Solid State 54, 866 (2012). 